\title{
Application of phytoncidal plants for improvement of ecological parameters of the air of library interiors
}

\author{
Tatiana Fershalova ${ }^{1,2^{*}}$, Elena Baikova $^{1}$, and Alina Ushakova $^{2}$ \\ ${ }^{1}$ Central Siberian Botanical Garden of the Siberian Branch of the Russian Academy of Sciences \\ (CSBG SB RAS), Novosibirsk 630090, Russia \\ ${ }^{2}$ Siberian state University of Geosystems and Technologies (SSUGT), Novosibirsk, 630108, Russia
}

\begin{abstract}
The results of the experiments on optimization of library room air with the help of the biological method are presented. Living tropical plants, volatile biologically active substances of which possess distinct antimicrobic properties are used for air sanitation. Their influence on change of the qualitative and quantitative microorganism composition in the air is shown. After plant placement the total number of colonies forming units (CFU) decreases by 3 times, that of staphylococcus - by 4.5 times. Air humidity increases insignificantly reaching the low limit of the comfort range for a person.
\end{abstract}

\section{Introduction}

In the world practice there is a wide experience of study of the ecological parameters of rooms of various functional purposes. The main ecological factors are temperature, humidity, air movement, qualitative and quantitative air microflora composition. These indices depend on many parameters: locality of a building, quality of used construction and finishing materials [1], as well as stay of people in the building [2]. People often spend $80 \%$ $-90 \%$ of time indoors [4]. In the indoor air environment there are many microorganisms bacteria, house fungi and viruses [3]. The person passes through himself by breath on the average $14 \mathrm{~m}^{3}$ of air per day [5]. He absorbs and secrets therewith volatile organic compounds (VOC), both endogenous and exogenous. Air quality indoors affects human performance and health as a whole $[2,6,7,8]$. Children are especially exposed to the risk of infection caused by poor air quality indoors $[9,10]$. They are more vulnerable to all types of environmental pollution compared to adults, as they breathe more air relative to body weight, the respiratory tract of children is not sufficiently developed [2,11]. Consequently, careful control of air and prevention of air pollution are essential in the premises of children's institutions [12]. Poor-quality indoor air of the libraries creates conditions for the appearance at employees and visitors of such diseases as: allergy, rhinitis, asthma and conjunctivitis [13]. Thus, a constant monitoring of the environmental factors promoting growth of air microorganisms and timely elimination of them are needed. There are various

\footnotetext{
*Corresponding author: fershalova@ngs.ru
} 
ways of cleaning indoor air. Usually recommendations on the improvement of air are reduced to airing of rooms and sanitary processing. The aim of our work is optimization of the air environment of library interiors with the help of ecological phytodesign method developed on the base of Central Siberian Botanical Garden (CSBG SB RAS) [14]. This method is ecologically safe, extremely economical and aesthetic. The essence is to use plants with distinct antimicrobic and gas-absorbing properties to reduce microbic and chemical air pollution.

\section{Material and methods}

The experiment was conducted in the building of the city library where educational activities with participation of children were carried out regularly. Two rooms similar in volume $\left(195 \mathrm{~m}^{3)}\right.$, air temperature $\left(+25 \mathrm{C}^{0}\right)$, air humidity $(20 \%)$ and illumination $(500-2000$ lx) were chosen. The windows faced the north-west. The experiment was conducted in the first room - hall of children's literature, the second room - literature issue hall was control. Air samples were taken in triplicate in five points for three days. The total microbic number of CFU, including Staphylococcus and moldy mushrooms in $1 \mathrm{~m}^{3}$ of air $\left(\mathrm{CFU} / \mathrm{m}^{3}\right)$ was counted. When making experiments, the air samples were taken before classes $(20$ children at 10-12 years old, duration of a class - $30 \mathrm{~min}$ ) and after them in both halls - with plants (experiment) and without them (control). Air intake was performed by the aspiration method based on the forced deposition of microorganisms on the surface of a dense nutrient medium. With the help of the sampling device (SD-1B) were pumped 1001 of air which fell on the surface of Petri dishes with meat-peptone agar (MPA). The samples were selected at the height of 1,5-1,8 $\mathrm{m}$ from the floor - at the level of human breathing. Cultivation of microorganisms was carried out in the thermostat at $+37 \mathrm{C}^{0}$ for 2 days. Microclimatic parameters - temperature, air humidity and illumination were measured by the combined device "TKA-PK" (UF). A phytomodule containing plants grown in the green houses of CSBG SB RAS and adapted to the interior conditions was set in the experimental room. The assortment of plants was selected according to techniques of ecological phytodesign [7]: Begonia «Loospe», B. «Loospe - tu», B. «Nigramarga», B. «November Frost», $B$. «Major», B. «Nigramarga», B. «Orange County», B. carolinifolia Reg., B. x erytrophylla Neumann, B. heracleifolia Cham. et Schlecht., Nephrolepis exaltata (L.) Schott «Fluffy Ruffles», Rhoeo discolor (L'Her.) Hance), Ruellia caroliniensis (J.F.Gmel.) Steud.), Pelargonium peltatum (L.) L'Her. ex Ait., Spathiphyllum wallisii Reg., Ficus Binnendijkii Miq «Alii», F. retusa L., Chlorophytum amaniense Engl. «Green Orange», Ch. comosum (Thunb.) Jacques «Bonnie», Ch. comosum «Variegatum», Schefflera octophylla (Lour.), Epipremnum aureum (Linden \& André) G.S.Bunting, «N'Joy». Calculation of the area of leaf surface of the phytomodule plants was made by the program "Siams photolab", the results were treated by "Microsoft Office Excel".

\section{Results}

In the course of the experiment air samples were taken in the rooms and the analysis of microorganisms grown on the nutrient medium was performed. The area of the leaf surface of plants required for getting sanitation effect was calculated. The optimal leaf area was $1,5-3 \mathrm{~m}^{2}$ per $100 \mathrm{~m}^{3}$ of air [7]. The leaf area in plants of the phytomodule amounted to $6,2 \mathrm{~m}^{2}$.

On the first day of the experiment, air composition in the control and experimental rooms was practically the same (Fig.1, sample I). Twenty four hours later CFU $/ \mathrm{m}^{3}$ in the room with the phytomodule decreased by three times (Fig.1, sample II). Forty eight hours later the difference in $\mathrm{CFU} / \mathrm{m}^{3}$ between the experiment and the control remained unchanged 
(Fig.1 sample III). Presence of children for 30 minutes increased significantly the quantity of microorganisms in the room air (Fig. 1, control), however, placement of plants allowed to decrease essentially $\mathrm{CFU} / \mathrm{m}^{3}$ in a day.

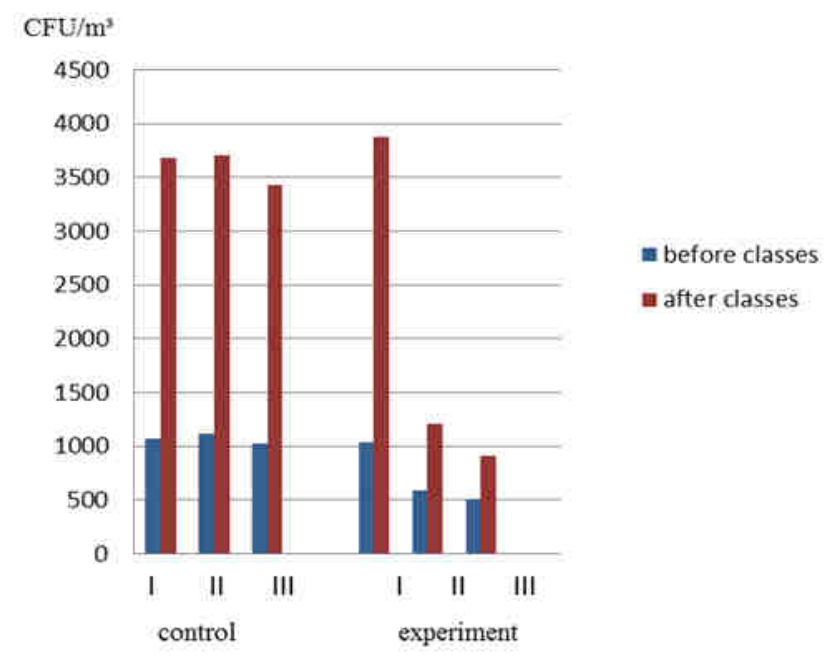

Fig. 1. Effect of plants on quantitative composition of air microflora in the room.

Figure 2 shows that the ratio of conditional-pathogenic microorganism microflora to constant one changed in the course of the experiment. In the control room Staphylococcus was more on $14 \%$ than in the room with plants.

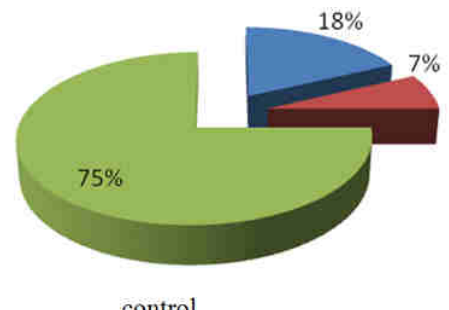

control

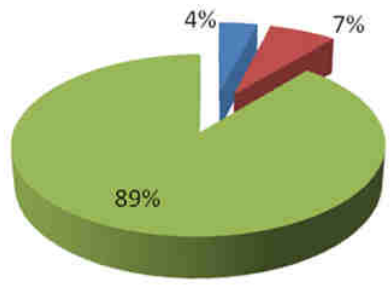

experiment

Constant microflora

Staphylococcus

Moldy mushrooms

Fig. 2. Ratio of conditional-pathogenic microflora to constant one in the presence of plants (experiment) and without them (control).

It was revealed that air humidity in the library was lowered. Relative air humidity in the hall of children's literature before installation of the phytomodule was $21,6 \%$. Forty eight hours after placement of plants air humidity amounted to 30,2\% (Fig. 3).

\section{Discussion}

The ecological status of the room air environment is made up from quantitative and qualitative indicators: total number of microorganisms and ratio of conditional-pathogenic microflora to constant one. The microorganisms moving freely in the air belong to the constant microflora (Micrococcus, Bacillus, Sarcina) and the conditional-pathogenic one 
(Staphylococcus, moldy mushrooms). Sanitary-hygienic state of a premise is characterized by the total number of all microorganisms in $1 \mathrm{~m}^{3}$ of air $-\mathrm{CFU} / \mathrm{m}^{3}$.

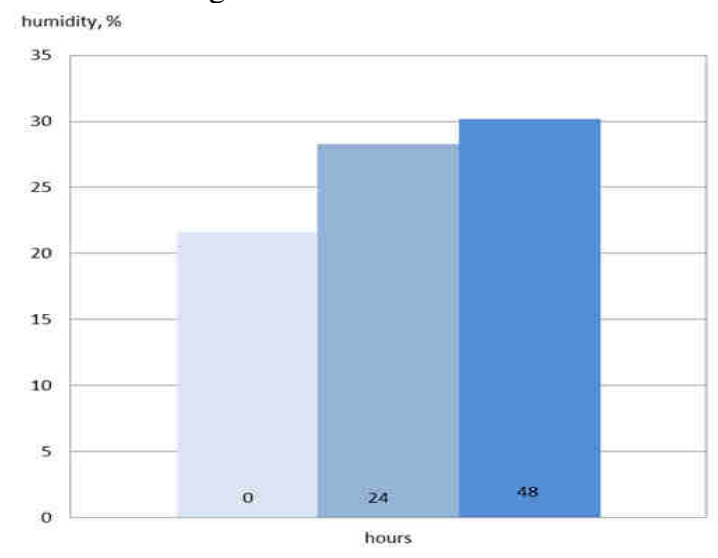

Fig. 3. Change in air humidity in the room after installation of the phytomodule.

In our experiment (control room) microorganism concentrations were in the range from 3435 to $3709 \mathrm{CFU} / \mathrm{m}^{3}$, which exceeded sanitary-hygienic standards $\left(2000 \mathrm{CFU} / \mathrm{m}^{3}\right)$. But those indicators were not the most high. For instance, J. M. Daisey noted that in the course of experiments carried out in schools and kindergartens were found concentrations of vital bacteria in the range from $7 \mathrm{CFU} / \mathrm{m}^{3}$ to $19500 \mathrm{CFU} / \mathrm{m}^{3}$ [15]. Microorganism concentrations in the university library were significantly lower and varied from 367 to $2595 \mathrm{CFU} / \mathrm{m}^{3}$ [5]. According to literature the number of bacteria in the room air environment increases due to presence of children [2]. We explain such an effect by the fact that adults are more static compared to children who often wave their hands, turn their heads, get up from their seats even during the classes. Such movements create chaotic flows of air currents in which there are different microorganisms. In the absence of air movement microorganisms gradually settle on the floor, and they are far less detectable at the level of breath of a person.

In the premises with library stock the main indicator of environmental well-being is quantity of moldy mushrooms colonies per $1 \mathrm{~m}^{3}$ of air as these microorganisms influence safety of books. The condition of air is considered satisfactory if quantity of moldy mushrooms per $1 \mathrm{~m}^{3}$ does not exceed 300-500 $\left(\mathrm{CFU} / \mathrm{m}^{3}\right)[13,16]$. However, we have paid attention not only to quantity of moldy mushrooms, but also to presence of Staphylococcus in the air. These microorganisms do not influence safety of library collection, but are a source of various diseases of the person $[17,18,19]$. It was shown in our experiment that in the air of library rooms Staphylococcus was more than moldy mushrooms. Such data are confirmed by other authors. A. Fox, \& R. M. T Rosario noted that concentration of grampositive bacteria, to which Staphylococcus belongs, was usually higher than concentration of gram-negative bacteria [20,21]. Staphylococcus, as a rule, gets to air from the mucosa of the respiratory tracts [18], but it may be on the surface of low-quality sanitary equipment [22] and even on the floor [21].

The results of our experiment show that application of ecological phytodesign method allows to improve air quality in premises of library. Thus, in a day after installation of phytomodules, value of $\mathrm{CFU} / \mathrm{m}^{3}$ decreased significantly, air humidity reached $30.2 \%$ - the lower limit of the comfort range for a person $(30 \%-60 \%)$. However, such air humidity is still below the norm recommended for storage of books and documents - 45-55\%. Each of premises has its own specifics, which should be taken into account when using the ecological phytodesign method. [14, 19, 22]. 
The work was carried out within the framework of the State Assignment of Central Siberian Botanical Garden SB RAS with partial support of Russian Foundation for Basic Research (project r_a №17-44-540601). When preparing the publication, the materials of bioresource scientific collection of CSBG SB RAS «Collections of living plants indoors and outdoors», № USU 44053 were used.

\section{References}

1. S. Torresin, G. Pernigotto, F. Cappelletti, et al., Indoor Air. Jul 28,525-538 (2018)

2. N. Canha, S.M. Almeida, M.C. Freitas, et al., Arch. Environ. Prot. 41, 11-22 (2015)

3. S.A. Wamedo, P.N. Ede, A. Chuku, Asian J. Biol. Sci. 5, 183-191 (2012)

4. A.H. Awad, S.A. Farag, Int. J. Environ. Health Res. 9, 313-319 (1999)

5. S.F. Hayleeyesus, A.M. Manaye, Asian Pac. J. Trop. Biomed. 4, 312-317 (2014)

6. V.A. Ivanchenko, A.M. Grodzinsky, T.M. Cherevchenko, et al., Phytoergonomics (Naukova Dumka, Kiev, 1989)

7. N.V. Tsybulya, T.D. Fershalova, Ecological basics of phytodesign (SGGA, Novosibirsk, 2013)

8. D. P. Wyon, Indoor Air 14, 92-101 (2004)

9. Yu.L. Yakimova, N.A. Rychkova, N.V. Tsybulya, Contem. Probl. Ecol. 2, 249-253 (2002)

10. E. Bragoszewska, A. Mainka, J.S. Pastuszka, et al., Atmosphere 9, 1-15 (2018)

11. P.T.B.S. Branco, R.A.O. Nunes, M.C.M Alvim-Ferraz, et al., Rev. Port. Pneumol. 22, 293-295 (2016)

12. T. Soto, M. Rosa, G. Murcia, et al., Anales de Biología 31, 109-115 (2009)

13. E.A. Agafonova, Recommendations on the work with photo documents from the State funds of the Russian Federation (State museum and exhibition center Russian Photo, St. Petersburg, 2012)

14. N.V. Tsybulya, T.D. Fershalova, Phytoncidal plants in the interior. Air sanitation with the help of plants (Novosibirsk Publishing House, Novosibirsk, 2000)

15. M. Daisey, W.J. Angell, M.G. Apte, Indoor Air 13, 53-64 (2003)

16. K. Konsa, M. Siiner, Theory and practice of preservation of cultural monuments 17, 916 (1995)

17. A.M. Andersson, N.Weiss, F. Rainey, et al., J. Appl. Microbiol. 86, 622-634 (1999)

18. O.V. Beresneva, New technologies in library and information practice and personneltraining (Perm, 2006)

19. N.V.Tsybulya, Yu.L. Yakimova, N.A.Rychkova, et al., Rastitelnye resursy 38, 112-117 (2002)

20. A. Fox, R.M.T. Rosario, Indoor Air 4, 239-247 (1994)

21. U. Lignell, Characterization of microorganisms in indoor environments (Univ. Kuopio Fac. Nat. and Environ. Sci., Diss., 2008)

22. N.V. Tsybulya, T.D. Fershalova, L.P. Davidovich, Izv. Samara Sci. Center, RAS 19, 360-364 (2017) 